\title{
Trace-Element Concentrations and Transport in the Coeur d'Alene River, Idaho, Water Years 1993-94
}

By Michael A. Beckwith, Paul F. Woods, and Charles Berenbrock

U.S. GEOLOGICAL SURVEY

Open-File Report 97-398

Boise, Idaho 


\title{
U.S. DEPARTMENT OF THE INTERIOR BRUCE BABBITT, Secretary
}

\author{
U.S. GEOLOGICAL SURVEY \\ Gordon P. Eaton, Director
}

The use of firm, trade, and brand names in this report is for identification purposes only and does not constitute endorsement by the U.S. Geological Survey.

For additional information write to:

District Chief

U.S. Geological Survey

230 Collins Road

Boise, ID 83702-4520
Copies of this report can be purchased from:

U.S. Geological Survey

Information Services

Box 25286

Federal Center

Denver, CO 80225 


\section{CONTENTS}

Abstract.tion
Introduction
Purpose and scope
Physiography and climate
Data collection and analysis
Trace-element concentrations and transport

\section{FIGURES}

1. Map showing location of study area

2. Graph showing comparison of annual discharge and trace-element (lead and zinc) loads at U.S. Geological Survey gaging stations on the Coeur d'Alene River, Idaho, water years 1993-94.

\section{TABLES}

1. Trace-element concentrations in samples collected at mid-depth at several verticals across the channel using a Van Dorn sampler, Coeur d'Alene River, Idaho

2. Mean concentrations and total annual loads of cadmium, copper, lead, and zinc at U.S. Geological Survey gaging stations on the Coeur d'Alene River, Idaho, water year 1993.

3. Mean concentrations and total annual loads of cadmium, copper, lead, and zinc at U.S. Geological Survey gaging stations on the Coeur d'Alene River, Idaho, water year 1994.

4. Hardness in water samples collected at U.S. Geological Survey gaging stations on the Coeur d'Alene River, Idaho.

5. Comparison of trace-element concentrations in filtered and whole-water samples collected at U.S. Geological Survey gaging stations on the Coeur d'Alene River, Idaho

\section{CONVERSION FACTORS AND VERTICAL DATUM}

\begin{tabular}{rcl}
\hline Multiply & \multicolumn{1}{c}{ By } & To obtain \\
\hline centimeter $(\mathrm{cm})$ & 0.3937 & inch \\
cubic meter per second $\left(\mathrm{m}^{3} / \mathrm{s}\right)$ & 35.31 & cubic foot per second \\
kilogram $(\mathrm{kg})$ & 2.205 & pound, avoirdupois \\
liter $(\mathrm{L})$ & 0.2642 & gallon \\
meter $(\mathrm{m})$ & 3.281 & foot \\
metric ton $(\mathrm{t})$ & 1.102 & ton, short $(2,000 \mathrm{lb})$ \\
micrometer $(\mu \mathrm{m})$ & 0.00003937 & inch \\
millimeter $(\mathrm{mm})$ & 0.03937 & inch \\
square kilometer $\left(\mathrm{km}^{2}\right)$ & 0.3861 & square mile \\
\hline
\end{tabular}

Sea Level: In this report, "sea level" refers to the National Geodetic Vertical Datum of 1929-a geodetic datum derived from a general adjustment of the first-order level nets of the United States and Canada, formerly called Sea Level Datum of 1929. 


\title{
TRACE-ELEMENT CONCENTRATIONS AND TRANSPORT IN THE COEUR D'ALENE RIVER, IDAHO, WATER YEARS 1993-94
}

\author{
By Michael A. Beckwith, Paul F. Woods, and Charles Berenbrock
}

\section{ABSTRACT}

For almost a century, the U.S. Geological Survey has collected hydrologic data at a network of stream-gaging stations throughout the Coeur d'Alene Lake and River drainage basin. Since 1990 , extensive water-quality data have been collected for a comprehensive study of potential eutrophication of Coeur d'Alene Lake and for assessment of the environmental effects of past mining and ore-processing activities in the South Fork Coeur d'Alene River valley.

Although the South Fork Coeur d'Alene River provided only about 20 percent of the Coeur d'Alene River's annual discharge to Coeur d'Alene Lake, it contributed as much as 84 percent of the annual cadmium and 83 percent of the annual zinc loads entering the Lake. The South Fork contributed at most 14 percent of the annual lead and 21 percent of the copper loads carried by the Coeur d'Alene River to Coeur d'Alene Lake. Cadmium, copper, and zinc loads more than doubled between the upstream and downstream boundaries of the Bunker Hill (Kellogg, Idaho) Superfund site in water years 1993 and 1994; lead load increased 24 percent and 33 percent, respectively, in water years 1993 and 1994.

Zinc was transported primarily in a dissolved or colloidal phase, the major source being the South Fork Coeur d'Alene River valley, downstream from the Elizabeth Park gaging station. Lead was transported primarily as particulate material, the major source being sediments eroded from the main-stem Coeur d'Alene River channel and flood plain. Annual lead and zinc loads at Rose Lake were significantly larger than at Harrison or Cataldo, indicating entrainment of trace elements in the reach between Cataldo and Rose Lake, and subsequent deposition or loss in the reach between Rose Lake and Harrison.

\section{INTRODUCTION}

From the late 1800 's to early 1980 's, the Coeur d'Alene Mining District was a major producer of silver, lead, and zinc. Mining and ore-processing activities introduced large amounts of trace-element enriched sediment into the South Fork Coeur d'Alene River (Ellis, 1940; Casner, 1989, 1991). Extensive timber harvest, wildfire, and airborne smelter emissions (which caused substantial localized devegetation) also caused significant erosion, sedimentation, and stream-channel alteration throughout the Coeur d'Alene River and Lake basin over the past century (Rabe and Flaherty, 1974).

Large amounts of sediment, highly enriched in trace elements such as cadmium, lead, and zinc, are associated with the channels and flood plains of the South Fork and main-stem Coeur d'Alene Rivers (Arthur J. Horowitz, U.S. Geological Survey, oral commun., 1995; Steve Box, U.S. Geological Survey, oral commun., 1997). These sediments continue to be eroded and redistributed, especially during spring runoff and floods. 


\section{Purpose and Scope}

As part of an integrated assessment of natural resource damages associated with past mining and ore-processing activities, the U.S. Geological Survey (USGS) collected hydrologic and water-quality data at six USGS gaging stations on the North Fork, South Fork, and main stem of the Coeur d'Alene River (fig. 1) during water years 1993 and 1994. These data were used to characterize trace-element concentrations and estimate transport (loading, or flux) through the lower Coeur d'Alene River Basin and into Coeur d'Alene Lake.

\section{Physiography and Climate}

The Coeur d'Alene River drains $3,810 \mathrm{~km}^{2}$ of the western slope of the Bitterroot Range in northern Idaho

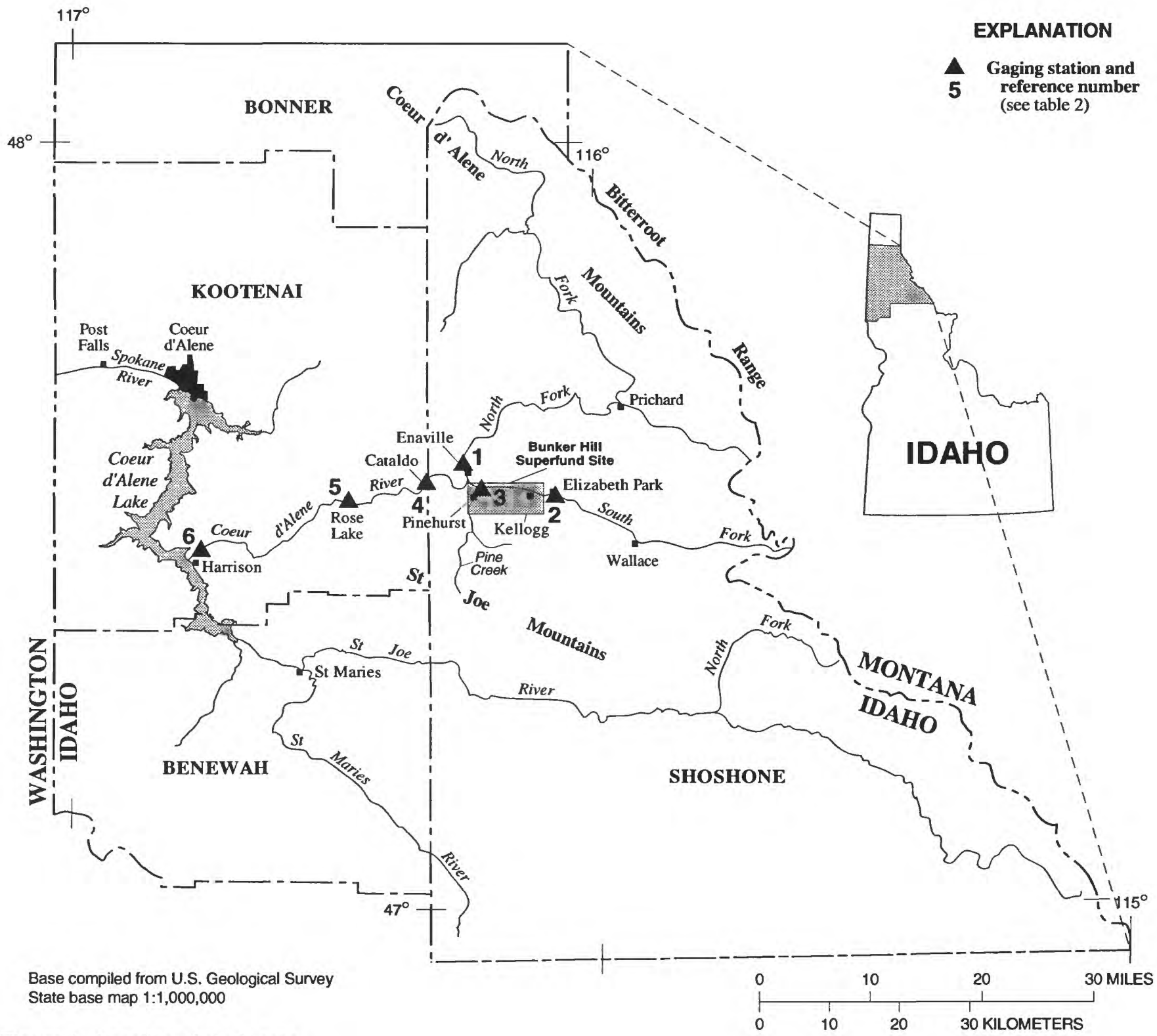

Figure 1. Location of study area. 
(fig. 1). Much of the area is mountainous and covered by dense, coniferous forests. Land surface in the Coeur d'Alene River Basin is more than 2,000 $\mathrm{m}$ above sea level at the Idaho-Montana border to $648 \mathrm{~m}$ above sea level at Coeur d'Alene Lake. Climate in the study area is subject to both marine and continental influences. Most precipitation occurs between November and April. Average annual precipitation is about $645 \mathrm{~mm}$ in the valleys and more than double that amount in the mountains. Occasional floods are due primarily to winter storms from the Pacific Ocean, when warm winds and heavy rains melt accumulated mountain snowpack.

Upper reaches of the Coeur d'Alene River are characterized by rocky, high-gradient stream channels, with numerous small tributaries and narrow flood plains confined by steep mountains. Downstream from the confluence of the North and South Forks, the Coeur d'Alene River is a meandering, low-gradient, valleybottom river. The deep silt/sand channel is in places confined by natural and constructed levees. The welldeveloped flood plain contains 12 shallow lateral lakes and includes extensive areas of wetland.

\section{DATA COLLECTION AND ANALYSIS}

Discharge at six gaging stations was determined from continuous monitoring of stage (water-surface elevation) and periodic measurements of streamflow using standard USGS methods (Buchanan and Somers, 1968, 1969; Carter and Davidian, 1968; Kennedy, 1983, 1984). Streamflow measurements generally were made weekly during spring runoff (March through May), biweekly to monthly during other times of the year, and also during significant floods.

In the lower main-stem Coeur d'Alene River, backwater conditions are created by seasonal regulation of Coeur d'Alene Lake level by the outlet dam at Post Falls (fig. 1). Backwater prevents correlation of river stage with streamflow. Therefore, daily discharge at the Rose Lake and Harrison gaging stations was estimated with the computer model FourPt. The model was developed by the USGS and is based on one-dimensional, partial-differential equations of continuity and momentum, which govern unsteady open-channel flow (DeLong and others, 1997). Model input included continuous discharge data at the Cataldo gaging station (fig. 1), contin-
Table 1. Trace-element concentrations in samples collected at mid-depth at several verticals across the channel using a Van Dorn sampler, Coeur d'Alene River, Idaho

[m, meters; $\mu \mathrm{g} / \mathrm{L}$, micrograms per liter]

\begin{tabular}{|c|c|c|c|c|c|}
\hline \multirow{2}{*}{$\begin{array}{c}\text { Gaging } \\
\text { station (date) }\end{array}$} & \multirow{2}{*}{$\begin{array}{c}\text { Distance } \\
\text { from right } \\
\text { bank }(\mathrm{m})\end{array}$} & \multicolumn{4}{|c|}{$\begin{array}{c}\text { Whole-water recoverable } \\
\text { concentrations }(\mu \mathrm{g} / \mathrm{L})\end{array}$} \\
\hline & & Cadmium & Copper & Lead & Zine \\
\hline \multirow{11}{*}{$\begin{array}{l}\text { Coeur d'Alene River } \\
\text { at Rose Lake } \\
\text { (Mar. 5, 1993) }\end{array}$} & 26.8 & 3 & 4 & 160 & 300 \\
\hline & 32.3 & 3 & 3 & 130 & 280 \\
\hline & 37.8 & 3 & 3 & 130 & 290 \\
\hline & 43.3 & 3 & 3 & 130 & 280 \\
\hline & 48.8 & 3 & 4 & 150 & 300 \\
\hline & 54.2 & 3 & 3 & 130 & 280 \\
\hline & 59.7 & 3 & 3 & 130 & 270 \\
\hline & 65.2 & 3 & 4 & 140 & 290 \\
\hline & 70.7 & 3 & 3 & 130 & 280 \\
\hline & 76.2 & 3 & 3 & 140 & 290 \\
\hline & Mean & 3 & 3.3 & 137 & 286 \\
\hline \multirow{16}{*}{$\begin{array}{l}\text { Coeur d'Alene River } \\
\text { near Harrison } \\
\text { (Oct. 20,1993) }\end{array}$} & 21.3 & 3 & 1 & 23 & \\
\hline & 25.9 & 2 & 1 & 21 & 530 \\
\hline & 30.5 & 2 & 1 & 21 & 540 \\
\hline & 35.0 & 2 & 1 & 20 & 520 \\
\hline & 39.6 & 2 & 1 & 19 & 530 \\
\hline & 44.2 & 3 & 1 & 21 & 530 \\
\hline & 48.8 & 2 & 1 & 19 & 510 \\
\hline & 53.3 & 2 & 1 & 18 & 510 \\
\hline & 57.9 & 2 & 1 & 19 & 520 \\
\hline & 62.5 & 2 & 1 & 19 & 520 \\
\hline & 67.1 & 2 & 1 & 20 & 520 \\
\hline & 71.6 & 2 & 1 & 19 & 510 \\
\hline & 76.2 & 2 & 1 & 19 & 510 \\
\hline & 80.0 & 2 & 1 & 19 & 520 \\
\hline & 85.3 & 2 & 1 & 18 & 520 \\
\hline & Mean & 2.1 & 1 & 19.7 & 520 \\
\hline
\end{tabular}

uous stage data at the Rose Lake and Harrison gaging stations, differences in elevation between these two stations and at 26 surveyed stream-channel cross sections located between them, and stream-channel characteristics such as shape and roughness. The model was calibrated to actual discharge measurements periodically made at the Cataldo, Rose Lake, and Harrison gaging stations.

Water samples were collected at the six gaging stations at fixed time intervals, generally weekly during spring runoff and monthly during the rest of the year. Samples also were collected during significant floods, because floods transport large quantities of dissolved and sediment-associated chemical constituents in short 
time periods. In water years $1993-94,14$ to 33 samples were collected at each of the six gaging stations.

Water samples were collected using standard USGS samplers and depth- and cross-section integrating methods (Edwards and Glysson, 1988). Depthintegrated sampling was not possible in the lower main-stem Coeur d'Alene River because channel depths of almost $15 \mathrm{~m}$ and velocities of less than $0.03 \mathrm{~m} / \mathrm{s}$ exceeded the design parameters of all generally available, noncontaminating, flow-integrating samplers. At the Rose Lake and Harrison stations, samples were collected at mid-depth, at the deepest point of the channel, using a 2.2-L Van Dorn sampler. On the basis of comparisons of individual samples collected at middepth, at 3 to 15 evenly spaced points (verticals) across the river channel, and collected on several occasions under various flow conditions, samples obtained in this manner adequately represented trace-element conditions throughout the channel. Table 1 presents selected data from these comparisons.

Samples were preserved with ultra-pure nitric acid at the time of collection. Whole-water (unfiltered) samples were analyzed for total recoverable concentrations of cadmium, copper, lead, and zinc by the USGS National Water Quality Laboratory (Fishman, 1993; Hoffman and others, 1996). This method employs an acid digestion step; it recovers dissolved trace elements and those adsorbed to particulate material in the water sample.

The quantity of trace elements transported annually at the six gaging stations was computed using the computer program FLUX (Walker, 1996). Program input included daily and instantaneous discharge, and total recoverable trace-element concentration data. The program computes loads by (1) direct mean loading, (2) flow-weighted concentration, (3) modified ratio estimate, (4) first-order regression, (5) second-order regression, and (6) individual daily streamflows. It includes data stratification and error analysis routines. The method that yielded the smallest coefficient of variation was considered the best estimate. FLUX also includes several diagnostic tools to assess results, such as plots of residuals, hypothesis tests for various model parameters, and data stratification scenarios.

\section{TRACE-ELEMENT CONCENTRATIONS AND TRANSPORT}

Mean annual discharge, mean trace-element concentrations, and total annual trace-element loads at six USGS gaging stations on the lower Coeur d'Alene River in water years 1993-94 are shown in tables 2 and 3. Trace-element concentrations in the South Fork Coeur d'Alene River are highly elevated compared with

Table 2. Mean concentrations and total annual loads of cadmium, copper, lead, and zinc at U.S. Geological Survey gaging stations on the Coeur d'Alene River, Idaho, water year 1993

[No., number; $\mathrm{m}^{3} / \mathrm{s}$, cubic meters per second; $\mu \mathrm{g} / \mathrm{L}$, micrograms per liter; kg, kilograms; NF, North Fork; SF, South Fork]

\begin{tabular}{|c|c|c|c|c|c|c|c|c|c|}
\hline \multirow[b]{2}{*}{$\begin{array}{l}\text { Gaging station and } \\
\text { reference No. }\end{array}$} & \multirow{2}{*}{$\begin{array}{c}\text { Annual } \\
\text { mean } \\
\text { atreamflow } \\
\left(\mathrm{m}^{3} / \mathrm{s}\right)\end{array}$} & \multicolumn{2}{|c|}{ Cadmium } & \multicolumn{2}{|c|}{ Copper } & \multicolumn{2}{|c|}{ Lead } & \multicolumn{2}{|c|}{ Zinc } \\
\hline & & $\begin{array}{c}\text { Mean } \\
\text { concentration } \\
\left(\mu g^{\prime} L\right)\end{array}$ & $\begin{array}{c}\text { Load } \\
\text { (kg) }\end{array}$ & $\begin{array}{c}\text { Mean } \\
\text { concentration } \\
\left(\mu g^{\prime} L\right)\end{array}$ & $\begin{array}{c}\text { Load } \\
\text { (kg) }\end{array}$ & $\begin{array}{c}\text { Mean } \\
\text { concentration } \\
(\mu g / L)\end{array}$ & $\begin{array}{c}\text { Load } \\
(\mathrm{kg})\end{array}$ & $\begin{array}{c}\text { Mean } \\
\text { concentration } \\
(\mu g / L)\end{array}$ & $\begin{array}{c}\text { Load } \\
(\mathbf{k g})\end{array}$ \\
\hline \multicolumn{10}{|l|}{ NF Coeur d'Alene River } \\
\hline at Enaville (1) & 43.3 & 1.0 & 1,370 & 2.5 & 3,440 & 4.5 & 6,190 & 17.1 & 23,320 \\
\hline \multicolumn{10}{|l|}{ SF Coeur d'Alene River } \\
\hline at Elizabeth Park (2) & 7.5 & 5.8 & 1,370 & 4.5 & 1,060 & 72.5 & 17,120 & 810.0 & 190,700 \\
\hline \multicolumn{10}{|l|}{ SF Coeur d'Alene River } \\
\hline near Pinehurst (3) & 12.1 & 8.0 & 3,040 & 7.7 & 2,920 & 55.8 & 21,190 & $1,130.0$ & 430,500 \\
\hline \multicolumn{10}{|l|}{ Coeur d'Alene River } \\
\hline at Cataldo (4) . . . . . . . . & 57.1 & 2.0 & 3,520 & 3.0 & 5,420 & 29.4 & 52,930 & 258.0 & 464,200 \\
\hline \multicolumn{10}{|l|}{ Coeur d'Alene River } \\
\hline at Rose Lake (5) & 57.6 & 2.3 & 4,630 & 3.9 & 7,860 & 142.0 & 286,300 & 347.0 & 699,500 \\
\hline \multicolumn{10}{|l|}{ Coeur d'Alene River } \\
\hline near Harrison (6). & 57.6 & 2.3 & 4,640 & 6.9 & 13,830 & 116.0 & 234,800 & 301.0 & 607,600 \\
\hline
\end{tabular}


Table 3. Mean concentrations and total annual loads of cadmium, copper, lead, and zinc at U.S. Geological Survey gaging stations on the Coeur d'Alene River, Idaho, water year 1994

[No., number; $\mathrm{m}^{3} / \mathrm{s}$, cubic meters per second; $\mu \mathrm{g} / \mathrm{L}$, micrograms per liter; kg, kilograms; NF, North Fork; SF, South Fork]

\begin{tabular}{|c|c|c|c|c|c|c|c|c|c|}
\hline \multirow[b]{2}{*}{$\begin{array}{l}\text { Gaging station and } \\
\text { reference No. }\end{array}$} & \multirow{2}{*}{$\begin{array}{c}\text { Annual } \\
\text { mean } \\
\text { streamflow } \\
\left(\mathbf{m}^{3} / \mathbf{s}\right)\end{array}$} & \multicolumn{2}{|c|}{ Cadmium } & \multicolumn{2}{|c|}{ Copper } & \multicolumn{2}{|c|}{ Lead } & \multicolumn{2}{|c|}{ Zinc } \\
\hline & & $\begin{array}{c}\text { Mean } \\
\text { concentration } \\
(\mu g / L)\end{array}$ & $\begin{array}{l}\text { Load } \\
(\mathbf{k g})\end{array}$ & $\begin{array}{c}\text { Mean } \\
\text { concentration } \\
(\mu g / L)\end{array}$ & $\begin{array}{l}\text { Load } \\
(\mathbf{k g g})\end{array}$ & $\begin{array}{c}\text { Mean } \\
\text { concentration } \\
(\mu g / L)\end{array}$ & $\begin{array}{l}\text { Load } \\
(\mathbf{k g g})\end{array}$ & $\begin{array}{c}\text { Mean } \\
\text { concentration } \\
(\mu \mathrm{g} / \mathrm{L})\end{array}$ & $\begin{array}{l}\text { Load } \\
(\mathbf{k g})\end{array}$ \\
\hline $\begin{array}{l}\text { NF Coeur d'Alene River } \\
\text { at Enaville (1) ........ }\end{array}$ & 26.5 & 1.0 & 840 & 2.4 & 1,990 & 2.9 & 2,420 & 13 & 10,900 \\
\hline $\begin{array}{l}\text { SF Coeur d'Alene River } \\
\text { at Elizabeth Park (2) } \ldots \ldots \ldots\end{array}$ & 5.0 & 6.6 & 1,050 & 3.5 & 560 & 42.0 & 6,670 & 1,000 & 159,600 \\
\hline $\begin{array}{l}\text { SF Coeur d'Alene River } \\
\text { near Pinehurst (3) } \ldots\end{array}$ & 7.8 & 8.7 & 2,150 & 3.8 & 940 & 35.8 & 8,840 & 1,310 & 324,400 \\
\hline $\begin{array}{l}\text { Coeur d'Alene River } \\
\text { at Cataldo (4) } \ldots \ldots \ldots \ldots \ldots\end{array}$ & 35.8 & 2.2 & 2,440 & 3.0 & 3,360 & 20.0 & 22,650 & 323 & 365,500 \\
\hline $\begin{array}{l}\text { Coeur d'Alene River } \\
\text { at Rose Lake (5) } \ldots \ldots \ldots \ldots \ldots \\
\text { Coeur d'Alene River }\end{array}$ & 38.5 & 2.2 & 2,670 & 2.8 & 3,460 & 86.7 & 105,300 & 376 & 456,800 \\
\hline near Harrison (6) $\ldots \ldots \ldots \ldots$ & 38.5 & 2.1 & 2,550 & 5.4 & 6,520 & 51.6 & 62,580 & 323 & 392,300 \\
\hline
\end{tabular}

average or background conditions expected to exist in waters throughout the Nation (Arthur J. Horowitz, U.S. Geological Survey, oral commun., 1997). Trace-element concentrations are not significantly elevated in the North Fork Coeur d'Alene River, where little mining activity took place. Trace-element concentrations also are elevated in the main-stem Coeur d'Alene River. Hardness data for the Coeur d'Alene River (collected from other USGS activities) are presented in table 4.

Figure 2 is a graphical comparison of annual discharge and annual loads of lead and zinc at six gaging stations in the lower Coeur d'Alene River Basin; loads entering Coeur d'Alene Lake at Harrison serve as the benchmark (or 100 percent). Although the South Fork Coeur d'Alene River provided only about 20 percent of the river's annual discharge into Coeur d'Alene Lake, it contributed 66 to 84 percent of the annual cadmium load and 71 to 83 percent of the annual zinc load, respectively, in water years 1993-94 (tables 2 and 3; fig. 2). In water years 1993-94, cadmium, copper, and zinc loads carried by the South Fork Coeur d'Alene River more than doubled between Elizabeth Park and Pinehurst (tables 2 and 3; fig. 2); lead load increased by 24 and 33 percent, respectively, in water years 199394. In contrast, the South Fork contributed 9 to 14 percent of the Coeur d'Alene River's total annual lead load, and 14 to 21 percent of the copper load to Coeur d'Alene
Table 4. Hardness in water samples collected at U.S. Geological Survey gaging stations on the Coeur d'Alene River, Idaho

[mg/L, milligrams per liter; $\mathrm{CaCO}_{3}$, calcium carbonate; No., number; $\mathrm{m}^{3} / \mathrm{s}$, cubic meters per second]

\begin{tabular}{|c|c|c|c|c|c|}
\hline \multirow[b]{2}{*}{ Gsging statlon } & \multirow[b]{2}{*}{$\begin{array}{l}\text { Perlod } \\
\text { of record }\end{array}$} & \multirow[b]{2}{*}{$\begin{array}{l}\text { No. of } \\
\text { aamples }\end{array}$} & \multicolumn{3}{|c|}{ Hardneas (as $\mathrm{mg} / \mathrm{L} \mathrm{CaCO}_{3}$ ) } \\
\hline & & & Mean & $\begin{array}{c}\text { Maximum (at } \\
\text { discharge, } \\
\mathrm{m}^{3} / \mathrm{s} \text { ) }\end{array}$ & $\begin{array}{c}\text { Minimum (at } \\
\text { dlscharge, } \\
\left.\mathrm{m}^{3} / \mathrm{s}\right)\end{array}$ \\
\hline $\begin{array}{l}\text { North Fork Coeur } \\
\text { d'Alene River } \\
\text { at Enaville.... } \\
\text { South Fork Coeur }\end{array}$ & $1971-94$ & 39 & 20.5 & $24(5.66)$ & $10(416)$ \\
\hline $\begin{array}{l}\text { d'Alene River } \\
\text { near Pinehurst. }\end{array}$ & 1987-95 & 20 & 71.8 & $100(2.12)$ & $27(71.9)$ \\
\hline $\begin{array}{l}\text { Coeur d'Alene River } \\
\text { at Cataldo.......... }\end{array}$ & $1986-95$ & 42 & 38.4 & $55(8.83)$ & $17(173)$ \\
\hline
\end{tabular}

Lake, respectively, in water years 1993-94 (tables 2 and 3; fig. 2).

The proportions of cadmium, copper, and zinc loads that can be attributed solely to the $54-\mathrm{km}^{2}$ Bunker Hill Metallurgical Complex Superfund site could not be determined in this study because contributions from the Pine Creek drainage (fig. 1), where mining and ore processing also took place, were not determined. Annual lead and zinc loads at Rose Lake (tables 2 and 3; fig. 2) were considerably larger than those at Cataldo and Harrison, indicating entrainment of trace elements between Cataldo and Rose Lake, and subsequent deposition or loss between Rose Lake and Harrison. 
Cadmium, copper, lead, and zinc loads in water year 1993 (table 2) were nearly two to four times larger than in 1994 (table 3). Annual discharge of the Coeur d'Alene River in water years 1993 and 1994 was about 80 and 50 percent, respectively, of the long-term average. Loads reported in tables 2 and 3 are probably less than what would be carried by higher discharges. They are probably substantially less than what actually occurred, because total sediment-associated traceelement transport was not accounted for in this study. Therefore, loads reported in tables 2 and 3 are most likely conservative estimates.
Data presented in table 5 suggest that cadmium and zinc are transported primarily in dissolved or solidphase associated (colloidal) form, which passes through a $0.45-\mu \mathrm{m}$ filter. The major source of cadmium, copper, and zinc in the lower Coeur d'Alene River Basin is the South Fork Coeur d'Alene River valley, downstream from the Elizabeth Park gaging station. Lead transport is associated with particulate material, to a greater degree than is copper. The primary source of lead and copper is deposits of trace-element enriched sediment eroded from the channels, banks, and flood plain of the main-stem Coeur d'Alene River (downstream from the confluence of the North and South Forks).
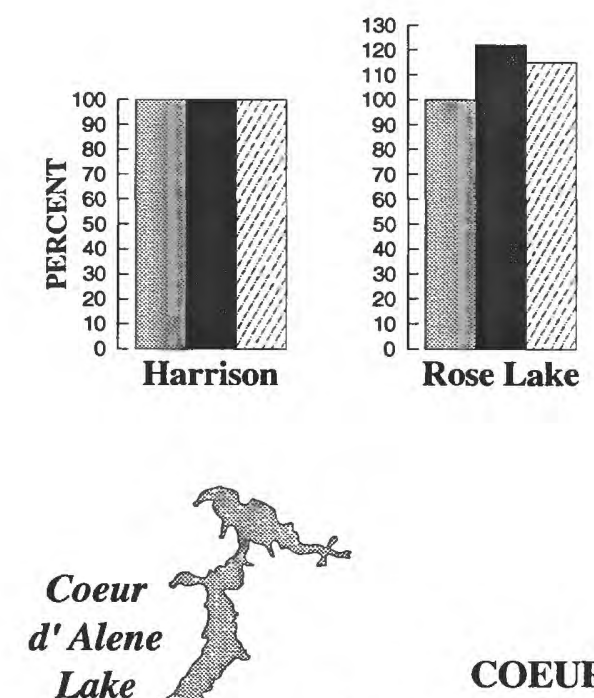

Lake
WATER YEAR 1993
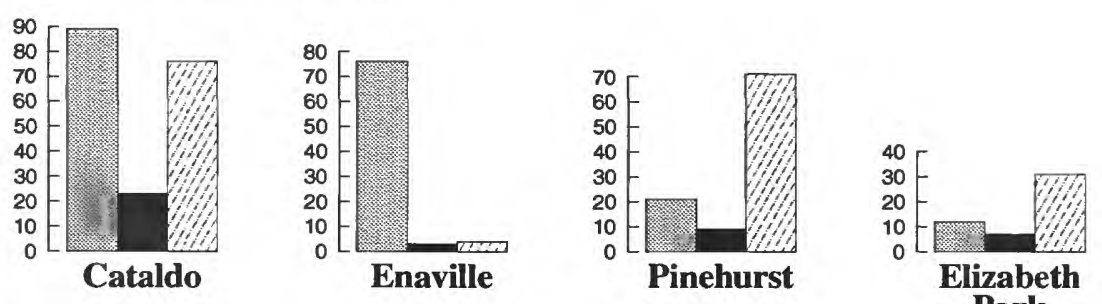

EXPLANATION

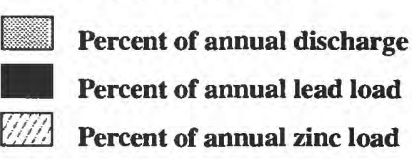

COEUR D'ALENE RIVER SCHEMATIC

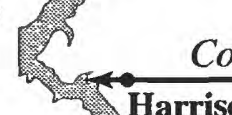

Coeurd'Alene
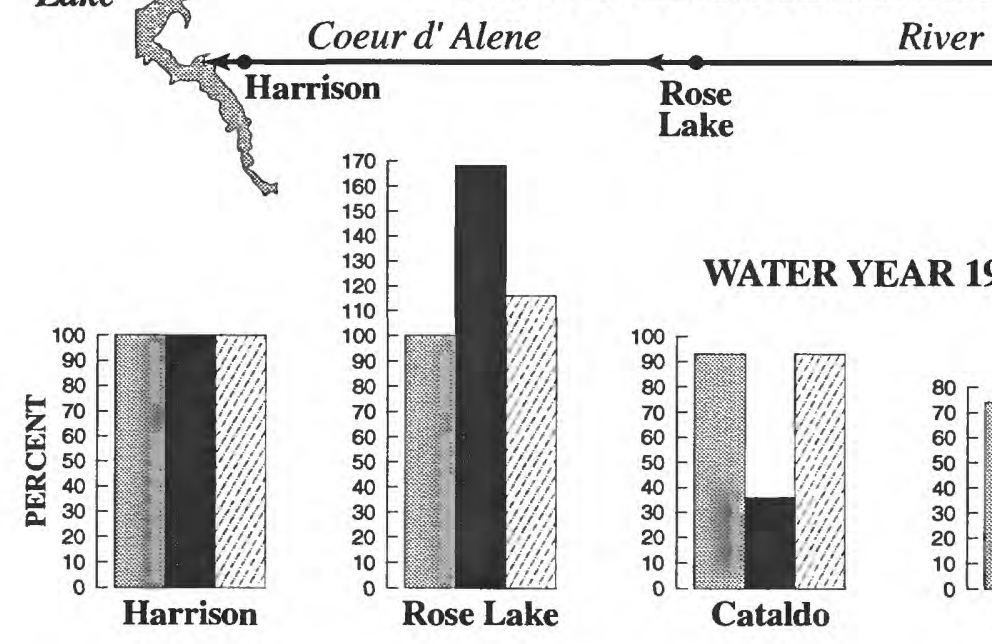

Rose
Lake

Cataldo
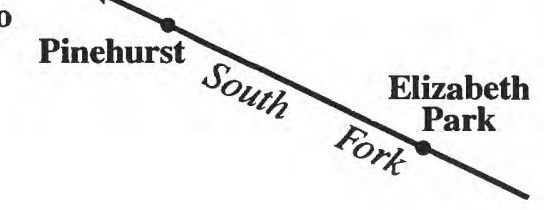

Rose Lake
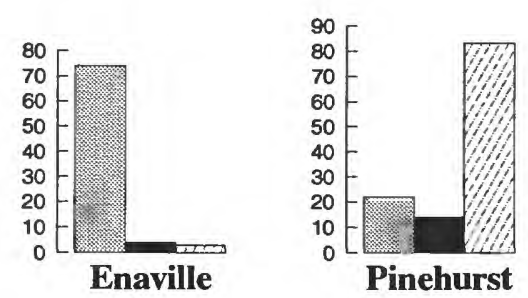

Figure 2. Comparison of annual discharge and trace-element (lead and zinc) loads at U.S. Geological Survey gaging stations on the Coeur d'Alene River, Idaho, water years 1993-94. (Loads entering Coeur d'Alene Lake at Harrison serve as the benchmark, or 100 percent) 
Table 5. Comparison of trace-element concentrations in filtered and whole-water samples collected at U.S. Geological Survey gaging stations on the Coeur d'Alene River, Idaho (Data from National Stream-Quality Accounting Network and other U.S. Geological Survey monitoring activities)

[ $\mu \mathrm{g} / \mathrm{L}$, micrograms per liter; WWR, whole-water recoverable; <, less than]

\begin{tabular}{|c|c|c|c|c|c|c|c|c|c|}
\hline \multirow[b]{2}{*}{ Gaging station } & \multirow{2}{*}{$\begin{array}{c}\text { Date } \\
\text { sampled }\end{array}$} & \multicolumn{2}{|c|}{ Cadmium ( $\mu \mathrm{g} / \mathrm{L})$} & \multicolumn{2}{|c|}{ Copper $(\mu g / L)$} & \multicolumn{2}{|c|}{ Lead $(\mu g / L)$} & \multicolumn{2}{|c|}{ Zinc $(\mu g / L)$} \\
\hline & & Filtered & WWR & Filtered & WWR & Filtered & WWR & Filtered & WWR \\
\hline \multirow{3}{*}{$\begin{array}{l}\text { North Fork Coeur d'Alene River } \\
\text { at Enaville................ }\end{array}$} & 9/21/93 & $<1$ & $<1$ & 4 & 4 & $<1$ & $<1$ & 13 & $<10$ \\
\hline & $5 / 20 / 93$ & $<1$ & $<1$ & 3 & 3 & 2 & 4 & 23 & 20 \\
\hline & $3 / 24 / 93$ & $<1$ & $<1$ & 1 & 5 & 1 & 7 & 20 & 40 \\
\hline \multirow{5}{*}{$\begin{array}{l}\text { South Fork Coeur d'Alene River } \\
\text { near Pinehurst ............. }\end{array}$} & 9/23/94 & 11 & 12 & 1 & 1 & 9 & 24 & 2,500 & 2,400 \\
\hline & $5 / 26 / 94$ & 5 & 5 & $<1$ & 3 & 7 & 19 & 890 & 870 \\
\hline & $3 / 16 / 94$ & 7 & 7 & 1 & 3 & 5 & 17 & 1,100 & 1,000 \\
\hline & $11 / 17 / 93$ & 15 & 11 & 2 & 2 & $<1$ & 14 & 2,500 & 2,500 \\
\hline & $3 / 23 / 93$ & 7 & 9 & 3 & 8 & 6 & 160 & 970 & 1,100 \\
\hline
\end{tabular}

This information can be used to develop and implement sound environmental cleanup actions and natural resource management strategies in the Coeur d'Alene River Basin. The approach used and the data base developed in this study also can serve as the basis for determining the effectiveness of ongoing and future cleanup actions and resource management strategies.

\section{REFERENCES CITED}

Buchanan, T.J., and Somers, W.P., 1968, Stage measurements at gaging stations: U.S. Geological Survey Techniques of Water Resources Investigations, book 3, chap. A7, $28 \mathrm{p}$.

1969, Discharge measurements at gaging stations: U.S. Geological Survey Techniques of Water Resources Investigations, book 3, chap. A8, 65 p.

Carter, R.W., and Davidian, J., 1968, General procedures for gaging streams: U.S. Geological Survey Techniques of Water Resources Investigations, book 3, chap. A6, $13 \mathrm{p}$.

Casner, N.A., 1989, Leaded waters: a history of mining pollution on the Coeur d'Alene River in Idaho, 1900-1950: Boise, Boise State University, unpublished M.S. thesis, $150 \mathrm{p}$.

1991, Toxic river: politics and Coeur d'Alene mining pollution in the 1930's: Idaho Yesterdays, v. 35, no. 3, p. 3-19.

DeLong, L.L., Thompson, D.B., and Lee, J.K., 1997, The computer program FourPt (version 95.01) - a model for simulating one-dimensional, unsteady, open-channel flow: U.S. Geological Survey Water-Resources Investigations Report 97-4016, 69 p.
Edwards, T.K., and Glysson, D.G., 1988, Field methods for measurement of fluvial sediment: U.S. Geological Survey Open-File Report 86-531, 118 p.

Ellis, M.M., 1940, Pollution of the Coeur d'Alene River and adjacent waters by mine wastes: Washington, D.C., U.S. Bureau of Fisheries Special Report no. 1, 61 p.

Fishman, M.J., 1993, Methods of analysis by the U.S. Geological Survey National Water-Quality Laboratorydetermination of inorganic and organic constituents in water and fluvial sediments: U.S. Geological Survey Open-File Report 93-125, 28 p.

Hoffman, G.L., Fishman, M.J., and Garbarino, J.R., 1996, Methods of analysis by the U.S. Geological Survey National Water-Quality Laboratory-in-bottle acid digestion of whole-water samples: U.S. Geological Survey Open-File Report 96-225, 217 p.

Horowitz, A.J., Elrick, K.A., Robbins, J.A., and Cook, R.B., 1995, A summary of the effects of mining and related activities on the sediment-trace metal geochemistry of Lake Coeur d'Alene, Idaho USA: Journal of Geochemical Exploration, v. 52, p. 135-144.

Kennedy, E.J., 1983, Computation of continuous records of streamflow: U.S. Geological Survey Techniques of Water Resources Investigations, book 3, chap. A13, $53 \mathrm{p}$.

-1984, Discharge ratings at gaging stations: U.S. Geological Survey Techniques of water resources investigations, book 3, chap. A10, 59 p.

Rabe, F.W., and Flaherty, D.C., 1974, The river of green and gold: Moscow, University of Idaho Research Foundation, $98 \mathrm{p}$.

Walker, W.W., 1996, Simplified procedures for eutrophication assessment and prediction, user manual: U.S. Army Corps of Engineers Waterways Experiment Station Instruction Report W-96-2, [variously paged]. 